\title{
A trip of peptides to the brain
}

\author{
Toshiro Matsui $^{1,2^{*}}$, Atsuko Yoshino ${ }^{1}$ and Mitsuru Tanaka ${ }^{2}$
}

\begin{abstract}
Dietary di/tripeptides elicit preventive effects against lifestyle-related diseases such as hypertension, and hypercholesterolemia, etc. Although there have been evidential reports that the intake of protein hydrolysate improved impaired memory in human, limited studies on bioavailability, in particular, beyond the blood-brain barrier (BBB) of candidates in hydrolysate may prevent their extensive physiological studies. Thus, this review discusses the updated studies on BBB transport of peptides showing improved cognitive decline. Furthermore, their accumulation in the brain cerebral parenchyma is also introduced.
\end{abstract}

Keywords: Peptide, Blood-brain barrier, Transport, Cognitive decline

\section{Introduction}

The physiological role of peptides is deemed important from the aspect of preventive lifestyle-related diseases, such as hypertension, diabetes, and atherosclerosis (Mine et al. 2010). Clinical evidences prove their effective health benefits in humans, for example, the anti-hypertensive effect shown by daily intake of small (di/tri) peptides, which modulate promoting blood pressure (Hata et al. 1996; Kawasaki et al. 2000). Antihypertensive effect of peptides (e.g., Val-Tyr) is closely associated with the suppression of promoting systemic and local renin-angiotensin (RA) systems by inhibiting angiotensin I-converting enzyme (ACE) activity. In addition, the suppression of local RA systems by peptides in the aorta and kidney (Matsui et al. 2003; Dias et al. 2017) extensively leads us to study the potential of peptides in local organs. Researchers have clarified the action of diverse peptides in improving degraded vessel functions (Matsui et al., 2012). Dias et al. (2017) have also reviewed the physiological potential of a dipeptide, Val-Tyr [angiotensin (3-4)], in the kidney through the inhibition of $\mathrm{Na}^{+}$reabsorption via the allosteric regulation of angiotensin-related receptors. Collectively, such

\footnotetext{
* Correspondence: tmatsui@agr.kyushu-u.ac.jp

${ }^{1}$ Department of Bioresources and Biosciences, Faculty of Agriculture, Graduate School of Kyushu University, 744 Motooka, Nishi-ku, Fukuoka 819-0395, Japan

${ }^{2}$ Research and Development Center for Five-Sense Devices, Kyushu University, 744 Motooka, Nishi-ku, Fukuoka 819-0395, Japan
}

reports strongly lead us to speculate that our body can accept peptides intestinally in intact form.

An epoch-making study on peptide absorption has been reported by Fei et al. (1994), who successfully cloned a human peptide transporter 1 (PepT1) from the cDNA library of rabbit intestine. PepT1 can recognize the structure of peptide bonding corresponding to di/tripeptides. Transporters related to peptide transport as a super family of proton-coupled oligopeptide transporters (POT), also known as a solute carrier 15 (SLC15), have been identified as PepT1/2 and peptide-histidine transporters (PHT)1/2 (Daniel and Kottra, 2004). They are located in diverse organs including the intestines, kidneys, spleen, liver, lungs, and brain, whereas their characteristics on peptide recognition at each organ/ transporter remain unclear. In particular, the biggest challenge for peptide transport is to account for the role of transporters expressed in the brain because peptide transporters expressed in the brain endothelial cells surrounded by pericytes, astrocyte, and neurons play a crucial role in the efflux (clearance) of peptidic metabolites from the cerebrospinal fluid (Jiang et al. 2009). In contrast, although Banks (2015) reviewed the blood-brain barrier (BBB) peptide transport systems, the uptake of peptides directed from blood to brain is a mystery. In this review, thus, we discuss the possibility of peptide transport through the BBB. Contribution of the preventive potential of peptides on brain functions is also

(c) The Author(s). 2020 Open Access This article is licensed under a Creative Commons Attribution 4.0 International License, which permits use, sharing, adaptation, distribution and reproduction in any medium or format, as long as you give appropriate credit to the original author(s) and the source, provide a link to the Creative Commons licence, and indicate if changes were made. The images or other third party material in this article are included in the article's Creative Commons licence, unless indicated otherwise in a credit line to the material. If material is not included in the article's Creative Commons licence and your intended use is not permitted by statutory regulation or exceeds the permitted use, you will need to obtain permission directly from the copyright holder. To view a copy of this licence, visit http://creativecommons.org/licenses/by/4.0/. 
reviewed from the point of view on memory and cognitive impairment.

\section{Transportability of peptides across the BBB}

Several assays, such as in vitro primary cell membrane, ex vivo sliced brain tissues or ventricle plexus, and in vivo brain perfusion experiments, have been performed for the evaluation of BBB transportability or uptake of compounds in the direction of blood to brain (influx) (Table 1). In vitro cell membrane experiments using rat primary cerebral microvascular endothelial cells are convenient and commercially available in the market. The in vitro transport (influx) assays of targets comprise a transwell chamber system with cells grown into the insert membrane. Carnosine ( $\beta$-Ala-His; Xiang et al. 2006), Pro-Pro-Leu (Hayes et al. 2016), and cyclo (Phe-Phe) (Tsuruoka et al. 2012) were reported to be transportable by the cell line experiments. Although the results on cell-crossing transport reveal the possibility of compounds capable of crossing the BBB in intact form, great attention should be paid regarding the evaluation of in vitro transportability from the aspect of $\mathrm{BBB}$ integrity. Low transendothelial electrical resistance (TEER) of cells cultured on transwell insert compared to in vivo BBB system (Hayes et al. 2016) suggests that the transportability obtained by cell line experiments may not be indicative beyond in vivo BBB barrier integrity or a meshwork of microvessel endothelial monolayer cells surrounded by pericytes and astrocytes, together with the tight-junction (TJ) composition (Hosoya et al. 2002) (Fig. 1). Therefore, in vivo transport experiments by target perfusion in mouse must provide substantial evidence to solve the mystery whether peptides can cross the $\mathrm{BBB}$ and accumulate into the cerebral parenchyma. In mouse treated by ligation of thoracic aorta, a perfusion solution containing targets is infused in the left of ventricle of the heart for a few minutes (Fig. 2). Thus, the observed influx profile of targets in the brain tissues by in situ transcardiac brain perfusion experiments demonstrates the intact transport of targets across the BBB under appropriate barrier integrity. Unfortunately, there is no striking evidence on intact influx of peptides beyond the BBB in literatures owing to severely controlled $\mathrm{BBB}$ and/or enzymatic degradation by proteases in blood and/or brain microvascular endothelial cells, except for some

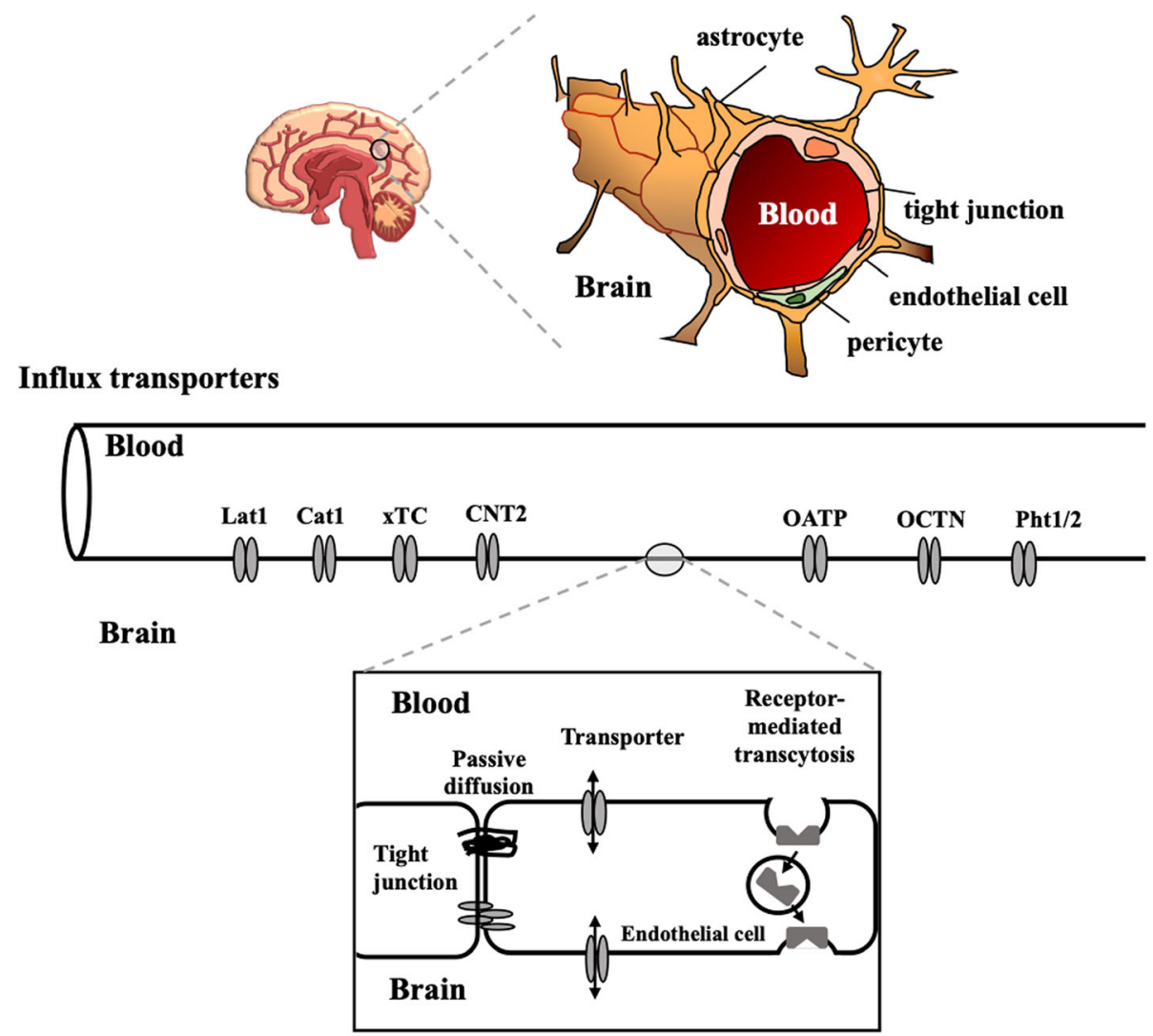

Fig. 1 Blood-brain barrier and transporters for influx routes. Lat1, large neutral amino acid transporter 1; Cat1, high affinity cationic amino acid transporter 1; xTC, cystine/glutamate transporter; CNT2, concentrative nucleoside transporter; OCTN, organic cation/carnitine transporter; OATP, organic anion transporting polypeptide; Pht1/2, peptide/histidine transporter 1/2 


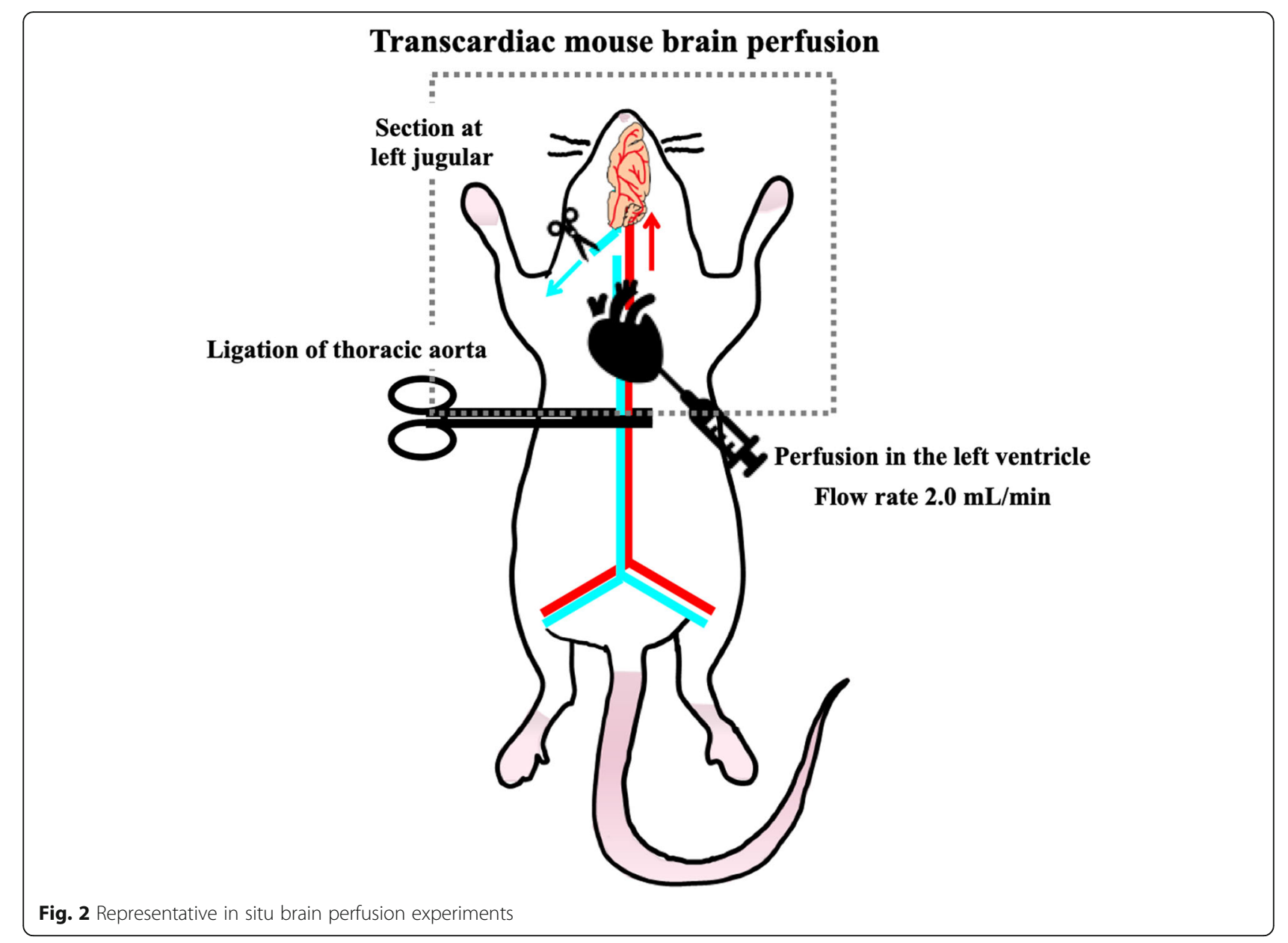

BBB transportable dipeptides as introduced in the later section.

\section{Blood-to-brain transporting peptides}

To explain whether peptides are of benefit for brain functions, in vivo evidence on peptides capable of influx transporting beyond the $\mathrm{BBB}$ must be provided prior to comparative study on transportability by in vitro cell line transport experiments, considering above issues regarding protease degradation and highly integrated barrier of the BBB. Thus, in situ perfusion experiments provide in vivo evidence on possible transportability of peptides in intact form across the BBB. The criteria for the selection of BBB transporting peptides is (1) a dipeptide skeleton [because transporters related to influx transport direction recognize small nutrients such as glucose and amino acids (Ogawa et al. 2020)], (2) PHT-1 substrate or dipeptides recognized by PHT1, which is abundantly expressed in the nerve system (Yamashita et al. 1997), and (3) hydrophobicity that may assist the transcellular diffusive transport (Nau et al. 1994). According to the criteria, the uptake (brain/perfusate ratio, $\mu \mathrm{L} / \mathrm{g}$-brain) of dipeptides listed in Table 2 is evaluated in in situ 2.0- min mouse perfusion experiments (Tanaka et al. 2019). In general, for example, fluorescein isothiocyanate conjugated (FITC)-albumin is used as negative control (or non-BBB transportable compound) to compensate a BBB membrane integrity (brain/perfusate ratio, $6.5 \mu \mathrm{L} / \mathrm{g}$ brain). $\mathrm{Hu}$ et al. (2014) revealed that Gly- $N$-methylated Gly (or Gly-Sar) that can be uptaken into the brain through the PHT1 in rodents (Hu et al. 2014) is preferably transported into mouse brain by 2.0 -min perfusion (brain/perfusate ratio, $24.5 \mu \mathrm{L} / g$-brain); the significantly high ratio compared to negative control (FITC-albumin) clearly indicates that peptides with at least two amino acid residues are capable of transporting across the BBB in the blood-to-brain direction in vivo. Among the 22 dipeptides, except for Gly-Sar, only two dipeptides (GlyPro and Tyr-Pro) show the higher brain/perfusion ratio than that of FITC-albumin; most dipeptides have no ability to cross the BBB (Table 2). In an in vitro incorporation study of histidine in PHT1-transfected oocytes, the uptake was inhibited in the co-presence of some dipeptides [His-Leu, $\beta$-Ala-His (carnosine), Met-Met, GlyLeu, and Gly-Gly], indicating that these dipeptides can be incorporated through the PHT1 (Yamashita et al. 
Table 1 The transportability of peptidic compounds across the blood-brain barrier

\begin{tabular}{|c|c|c|c|c|c|}
\hline Penetrant & $\begin{array}{l}\text { Cell or } \\
\text { animal }\end{array}$ & $\begin{array}{l}\text { Influx or } \\
\text { efflux }\end{array}$ & Time & Data & Doi \\
\hline cyclo(Phe-Phe) & cell & influx & $\begin{array}{l}20,40 \\
60 \mathrm{~min}\end{array}$ & $P_{\mathrm{app}}=\sim 25 \times 10^{-6} \mathrm{~cm} / \mathrm{s}$ & $\begin{array}{l}\text { doi:10.1371/ } \\
\text { journal.pone.0050824 }\end{array}$ \\
\hline Pro-HyPa & rat & influx & $30 \mathrm{~min}$ & $\begin{array}{l}\sim 0.5 \mathrm{nmol} / \mathrm{mL} \text {-cerebrospinal fluid } \\
\text { (ginger-degraded collagen hydrolysate } \\
600 \mathrm{mg} / \mathrm{kg} \text { p.o.) }\end{array}$ & doi:10.1096/fj.201902871R \\
\hline Trp-Tyr & rat & influx & $2 \mathrm{~h}$ & $\begin{array}{l}\text { tissue/plasma ratio : } 0.23 \\
\text { (hippocampus) }\end{array}$ & doi:10.18632/aging.101909 \\
\hline Leu-His & rat & influx & $2 \mathrm{~h}$ & $\begin{array}{l}\text { tissue/plasma ratio : } 0.19 \\
\text { (hippocampus) }\end{array}$ & doi:10.3390/nu11092161 \\
\hline Met-Lys-Pro & rat & influx & $15 \min$ & autoradiographic image & $\begin{array}{l}\text { doi:10.1371/ } \\
\text { journal.pone.0171515 }\end{array}$ \\
\hline Gly-Sar & $\begin{array}{l}\text { mouse brain } \\
\text { slice }\end{array}$ & influx & $10 \mathrm{~min}$ & Uptake $=\sim 110 \mu \mathrm{L} / \mathrm{g}$ (hippocampus) & doi:10.1111/jnc.12687 \\
\hline cyclo(His-Pro) & mousse (i.v) & influx & $120 \mathrm{~min}$ & $K_{\mathrm{i}}=0.179 \mu \mathrm{L} / \mathrm{g}-\mathrm{min}$ & $\begin{array}{l}\text { doi:10.1152/ } \\
\text { ajpendo.1993.264.5.E723 }\end{array}$ \\
\hline kyotorphin ( Tyr-Arg ) & mouse (i.c.v.) & efflux & $2-15 \min$ & $\mathrm{t}_{1 / 2}=4.9 \mathrm{~min}$ & $\begin{array}{l}\text { doi:10.1111/j.1471- } \\
\text { 4159.2009.06090.x }\end{array}$ \\
\hline \multirow[t]{2}{*}{ histidine } & $\begin{array}{l}\text { mouse brain } \\
\text { slice }\end{array}$ & influx & $3 \mathrm{~min}$ & Uptake $=\sim 0.09 \mu \mathrm{L} / \mathrm{g}$ (hippocampus) & doi:10.1016/j.bcp.2016.11.012 \\
\hline & $\begin{array}{l}\text { mouse(1 } \\
\mathrm{nmol} / \mathrm{g}: i . v)\end{array}$ & influx & $\begin{array}{l}0 \sim 30 \\
\min \end{array}$ & $\begin{array}{l}\text { concentration }=\sim 0.5 \mathrm{nmol} / \\
\text { g(hippocampus) }\end{array}$ & doi:10.1016/j.bcp.2016.11.012 \\
\hline $\begin{array}{l}\text { oxytocin [ CYINQCPLG } \\
\text { ( Disulfide bridge: 1-6 ) ] }\end{array}$ & cell & influx & $3 \mathrm{~h}$ & $P_{\text {app }}=3.03 \times 10^{-6} \mathrm{~cm} / \mathrm{s}$ & doi:10.1038/s42003-019-0325-6 \\
\hline neuropeptide $Y$ & mouse & influx & 2-30 min & $K_{\mathrm{i}}=0.194 \mu \mathrm{L} / \mathrm{g}-\mathrm{min}$ & $\begin{array}{l}\text { doi:10.1152/ } \\
\text { ajpendo.1999.276.3.E479 }\end{array}$ \\
\hline endomorphin & rat & influx & $\begin{array}{l}15-60 \\
\min \end{array}$ & HPLC Chromatogram & $\begin{array}{l}\text { doi:10.1016/ } \\
\text { j.regpep.2005.12.004 }\end{array}$ \\
\hline alanine & mouse & influx & $5 \mathrm{~min}$ & $P_{\mathrm{app}}=9.6 \pm 0.8 \times 10^{-6} \mathrm{~cm} / \mathrm{s}$ & doi:10.1016/j.tiv.2004.06.011 \\
\hline L-dopa & mouse & influx & $5 \mathrm{~min}$ & $P_{\mathrm{app}}=3.9 \pm 0.79 \times 10^{-6} \mathrm{~cm} / \mathrm{s}$ & doi:10.1016/j.tiv.2004.06.011 \\
\hline leucine & mouse & influx & $5 \mathrm{~min}$ & $P_{\text {app }}=14.6 \pm 1.9 \times 10^{-6} \mathrm{~cm} / \mathrm{s}$ & doi:10.1016/j.tiv.2004.06.011 \\
\hline apolipoprotein J & mouse & influx & $\begin{array}{l}1.0-10 \\
\min \end{array}$ & $K_{\mathrm{i}}=3.75 \mu \mathrm{L} / \mathrm{g}-\mathrm{min}$ & $\begin{array}{l}\text { doi:10.1016/s0024- } \\
\text { 3205(96)00685-6 }\end{array}$ \\
\hline SAM 995 ( Tyr-D-Thr-Gly-Phe-Leu-Ser ) & rat & influx & $\begin{array}{l}5.0-20 \\
\min \end{array}$ & $K_{\mathrm{i}}=1.0 \pm 0.2 \mu \mathrm{L} / \mathrm{g}-\mathrm{min}$ & $\begin{array}{l}\text { http://jpet.aspetjournals.org/ } \\
\text { content/299/3/967 }\end{array}$ \\
\hline $\begin{array}{l}\text { SAM } 1095 \text { ( O-linked Ser- }-\beta-D \text { - } \\
\text { glucose analog of SAM995) }\end{array}$ & rat & influx & $\begin{array}{l}5.0-20 \\
\min \end{array}$ & $K_{\mathrm{i}}=2.2 \pm 0.3 \mu \mathrm{L} / \mathrm{g}-\mathrm{min}$ & $\begin{array}{l}\text { http://jpet.aspetjournals.org/ } \\
\text { content/299/3/967 }\end{array}$ \\
\hline $\begin{array}{l}\text { DPDPE ( Tyr-D-penicillamine-Gly-Phe- } \\
\text { D-penicillamine ) }\end{array}$ & rat & influx & $30 \mathrm{~min}$ & $K_{\mathrm{i}}=1.46 \pm 0.31 \mu \mathrm{L} / \mathrm{g}-\mathrm{min}$ & $\begin{array}{l}\text { doi:10.1046/j.1471- } \\
\text { 4159.1996.66031289.x }\end{array}$ \\
\hline valproic acid & rat & influx & $\begin{array}{l}0.25-0.5 \\
\min \end{array}$ & $K_{\mathrm{i}}=\sim 480 \mu \mathrm{L} / \mathrm{g}-\mathrm{min}$ & $\begin{array}{l}\text { http://jpet.aspetjournals.org/ } \\
\text { content/276/3/1189 }\end{array}$ \\
\hline amantadin & mouse & influx & $\begin{array}{l}10-20 \\
\text { sec }\end{array}$ & $K_{\mathrm{i}}=102 \mu \mathrm{L} / \mathrm{g}-\min$ & doi:10.1002/bdd.2014 \\
\hline clonidine & mouse & influx & $\begin{array}{l}0.5-3.0 \\
\min \end{array}$ & $K_{\mathrm{i}}=366 \mu \mathrm{L} / \mathrm{g}-\min$ & doi:10.1038/jcbfm.2009.54 \\
\hline
\end{tabular}

${ }^{\mathrm{a} H y P}$ hydroxyl Pro

1997). However, no uptake of His-Leu in mouse perfusion experiments (Table 2) led us to consider that BBB transportable peptides highly require protease resistance in blood and in brain microvascular endothelial cells in the BBB transporting process. Thus, no uptake (brain/ perfusion ratio of less than that of FITC-albumin) of most dipeptides (Table 2) indicates inability to cross the
BBB owing to their poor protease resistance in vivo, apart from substrate affinity with $\mathrm{BBB}$ transporters and hydrophobicity.

The $K_{\mathrm{i}}$ values of two BBB transportable dipeptides, Gly-Pro and Tyr-Pro, are 3.49 and $3.53 \mu \mathrm{L} / \mathrm{g} \cdot \mathrm{min}$, respectively, showing the lower transportability $(7.6 \mu \mathrm{L} /$ g.min) of the reported $\mathrm{BBB}$ transportable model 
Table 2 Brain/perfusion ratio of dipeptides in mouse perfusion experiments

\begin{tabular}{|c|c|c|c|}
\hline Peptide & $\log P$ & $\begin{array}{l}\text { Brain/Perfusate Ratio } \\
\text { ( } \mu \mathrm{L} / \mathrm{g} \text {-wet brain) }\end{array}$ & $K_{\mathrm{i}}(\mu \mathrm{L} / \mathrm{g}-\min )$ \\
\hline FITC-albumin & & $6.46 \pm 0.15$ & $-0.52 \pm 0.50$ \\
\hline Trp-Leu & 1.623 & no uptake & - \\
\hline Leu-Trp & 1.019 & no uptake & - \\
\hline Trp-Met & 1.004 & no uptake & - \\
\hline Trp-Tyr & 0.212 & no uptake & - \\
\hline Tyr-Pro & 0.202 & $10.5 \pm 1.3$ & $3.53 \pm 0.74$ \\
\hline Ile-Tyr & -0.249 & no uptake & - \\
\hline Leu-Tyr & -0.249 & no uptake & - \\
\hline Pro-Tyr & -0.398 & no uptake & - \\
\hline His-Leu & -0.477 & no uptake & - \\
\hline Trp-His & -0.555 & no uptake & - \\
\hline Gly-Pro & -0.602 & $10.85 \pm 0.99$ & $3.49 \pm 0.66$ \\
\hline Val-Tyr & -0.758 & no uptake & - \\
\hline His-Pro & -0.881 & no uptake & - \\
\hline Met-Tyr & -0.888 & no uptake & - \\
\hline Leu-His $^{a}$ & -1.016 & no uptake & - \\
\hline Tyr-His ${ }^{a}$ & -1.164 & no uptake & - \\
\hline Tyr-Arg ${ }^{a}$ & -1.269 & no uptake & - \\
\hline Ser-Pro & -1.634 & no uptake & - \\
\hline Gly-Sar & -1.651 & $24.54 \pm 1.78$ & $7.60 \pm 1.29$ \\
\hline Ser-Tyr ${ }^{a}$ & -2.371 & no uptake & - \\
\hline Ala-Gln & -2.581 & no uptake & - \\
\hline Ala-Glu ${ }^{a}$ & -2.581 & no uptake & - \\
\hline Ser-His ${ }^{a}$ & -3.139 & no uptake & - \\
\hline
\end{tabular}

$\log P$ values are cited from SciFinder (https://scifinder.cas.org/scifinder/view/ scifinder/scifinderExplore.jsf)

no uptake : below the ratio of FITC-albumin of $<6.46 \mu \mathrm{L} / \mathrm{g}$-wet brain $(2 \mathrm{~min}$ ) or $7.34 \mu \mathrm{L} / \mathrm{g}$-wet brain $(10 \mathrm{~min}$ )

${ }^{a} 10$ min-perfusion

dipeptide, Gly-Sar (Hu et al. 2014) (Table 2). The $K_{\mathrm{i}}$ values or transportabilities of Gly-Pro and Tyr-Pro are higher than those of other reported oligopeptides [e.g., $3 \mu \mathrm{L} / \mathrm{g} \cdot \mathrm{min}$ for neuropeptide $\mathrm{Y}$ (36 amino acids) (Kastin \& Akerstrom 1999), $0.84 \mu \mathrm{L} / \mathrm{g} \cdot \mathrm{min}$ for growth hormone (191 amino acids) (Pan et al. 2005), and $0.57 \mu \mathrm{L} / \mathrm{g} \cdot \mathrm{min}$ for peptide hormone ghrelin (28 amino acids) (Banks 2002)] but much lower than those of chemical drugs (e.g., valproic acid) (Adkison \& Shen 1996)(Table 1). The brain/perfusate ratio of $10.5 \pm 1.3 \mu \mathrm{L} / \mathrm{g}$-brain for Tyr-Pro (Table 2) compatible with the BBBtransportable L-DOPA $(19.3 \pm 5.9 \mu \mathrm{L} / \mathrm{g}$-brain) (Ko et al. 2015) also suggests acceptable and preferable BBB transportability of Gly-Pro and Tyr-Pro. Although the structure-transportability relationship remains unascertained within the limited transport studies, it seems probably that (1) BBB transportable peptides in the blood-to-brain direction are restrictive to small peptides with high protease resistance (see Fig. 3), (2) peptide sequence, but not hydrophobicity, may determine the $\mathrm{BBB}$ transport (as Pro-Tyr, a reversed sequence of BBB transportable Tyr-Pro, shows no uptake; Table 2), and (3) the transportability of peptide is low enough to compare to drugs.

\section{Transport route of BBB transportable peptides}

The BBB regulates or limits compounds acceptable for the brain, including amino acids, glucose, organic/inorganic compounds, and vitamins, whereas large compounds fail the BBB transport (Ogawa et al. 2020). Thus, transporters capable of recognizing and transporting nutrients are individually expressed at luminal and abluminal sides of the BBB; typical influx (blood to brain direction) transporters are glucose transporter 1 (GLUT1) for glucose, large neutral amino acid transporter 1 (LAT1), and monocarboxylate transporter 1 (MCT1). For the uptake of peptides across the BBB, PHT1 is probably involved in the BBB transporting route because the incorporation of histidine, a substrate of PHT1, was inhibited by dipeptides in PHT1-expressed oocyte (Yamashita et al. 1997). Ex vivo perfusion experiments using brain tissue slices also demonstrate the BBB transport route of Gly-Sar through the PHT1 (Hu et al. 2014). However, in vivo mouse co-perfusion study of PHT1 substrates with the BBB transportable dipeptide, Tyr-Pro, provides another possible transporting route of peptides; the uptake of Tyr-Pro, but not Gly-Sar, is inhibited by histidine and L-DOPA (Tanaka et al. 2019). Considering the reported substrate specificity of PHT1 and LAT1 for histidine (Alexander et al. 2015), LAT1 for L-DOPA (del Amo et al. 2008), and PHT1 for GlySar (Hu et al. 2014), LAT1 cannot be ruled out for the BBB transport route of dipeptides, together with PHT1. Additionally, a peptide transport system for octapeptide (Peptide T, derived from the human immunodeficiency virus (HIV) envelope glycoprotein) (Barrera et al. 1987) and a transcellular diffusive route by passive or endocytosis penetration pathways (Guidotti et al. 2017) for hydrophobic peptides such as cell penetrating peptides (Rhee and Davis 2006) and delta sleep-inducing peptide (Banks et al. 1986) might be involved in the blood-tobrain uptake of dipeptides (Fig. 1).

\section{Location of peptides in the brain}

Matrix-assisted laser desorption/ionization mass spectrometry (MALDI-MS) imaging technique is an extensive and advanced visualization tool having wide applications in spatial localization of targets in terms of tissue distribution, such as immunostaining. This is because it possesses great advantage of non-targeting detection for a wide mass range of ionizable compounds 


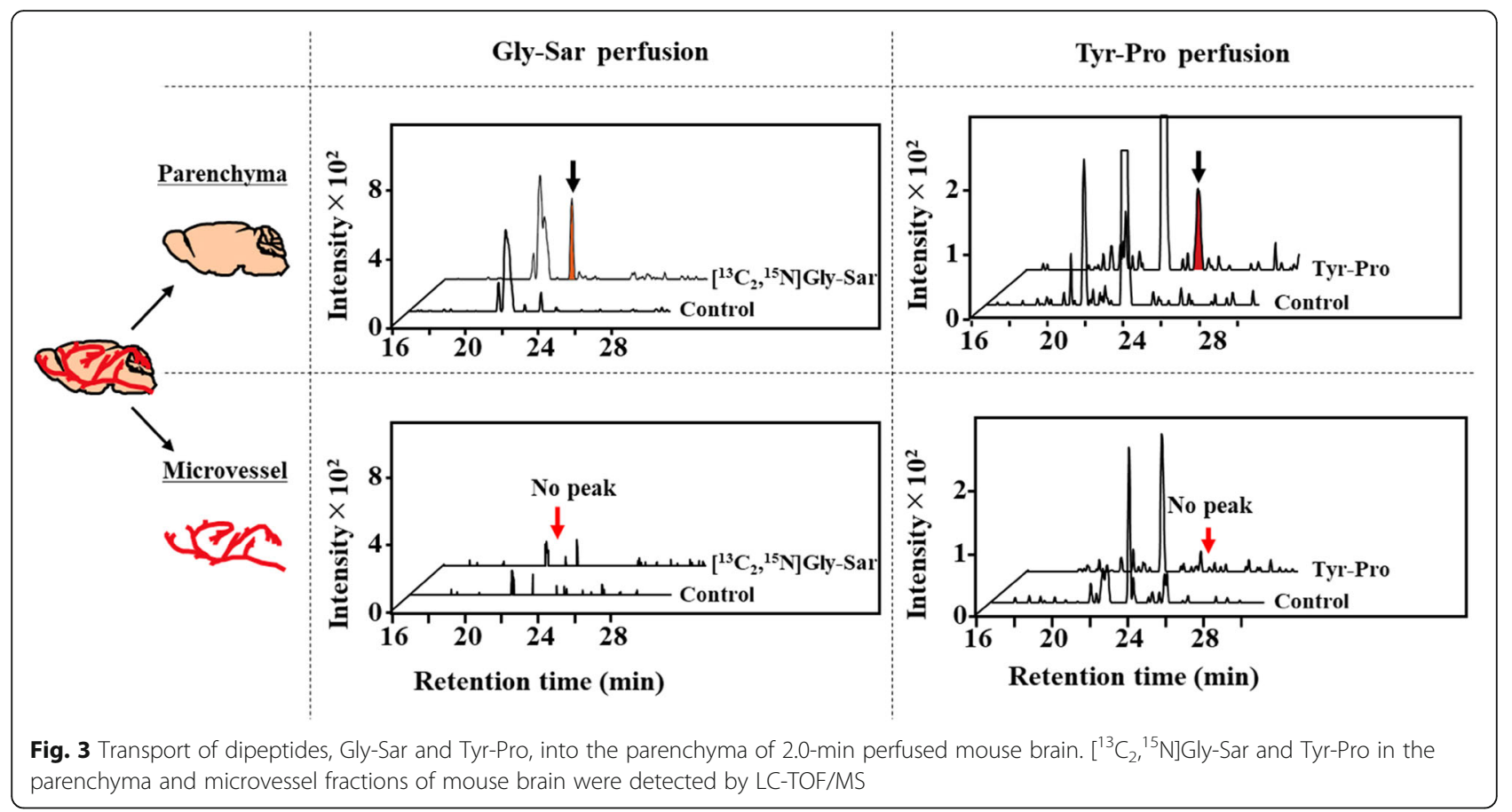

such as proteins, lipids, and drug molecules with no use of antigens (Nguyen et al. 2019; Yoshimura \& Zaima 2020). The outstanding observation for brain visualization study is the report by Shariatgorji et al. (2014), who simultaneously visualized neurotransmitters, including tyramine, dopamine, and acetylcholine, in mouse brain tissues using MALDI-MS imaging in combination with amine-specific derivatization. Liu et al. (2013) also demonstrate the advantage of MALDI-MS imaging for non-targeting visualization of EGFR inhibitory drug, erlotinib, beyond the BBB in mouse brain, wherein the drug and its metabolites were visually localized at the tumor region of mouse brain. The novelty of the phytic acid-aided MALDI-MS imaging technique (Hong et al. 2013) could be applied for the histological distribution of Tyr-Pro capable of crossing the BBB in intact form (Fig. 3). As depicted in Fig. 4, it seems probable that Tyr-Pro may preferably accumulate in the hippocampus, hypothalamus, striatum, cerebral cortex, and cerebellum of the mouse brain after $<10$ min-perfusion. The accumulated regions of Tyr-Pro in the mouse brain are closely associated with memory consolidation and spatial memory (hippocampus) (Squire et al. 2015), food intake control (hypothalamus), and cognition (cerebrum and cerebellum) (Buckner 2013). The accumulation of BBB transporting dipeptides in brain parenchyma is unknown because there have been no comparable reports so far. However, the evidential observation by MALDI-MS imaging could indicate a potential physiological function of dipeptides in the brain.

\section{Perspective}

Nowadays, a cognitive dysfunction is a serious social issue in aged population, whereas appropriate therapeutic drugs or preventive food-style are less available. The evidential in vivo reports that a soybean hydrolysate richly containing di/tripeptides improved a delayed memory score in patients with mild cognitive impairment (Maebuchi et al., 2013) and suppressed a cognitive decline in SAMP8 mice (Katayama et al. 2014) strongly lead us to hypothesize that daily intake of some brainhealth peptides has physiological potential to prevent the onset of dementia including Alzheimer's disease. Although in this review, peptides crossing the BBB in intact form are discussed, little is known about their brain-benefit roles. Previous reports of di/tripeptides showing in vivo prevention effect of dementia are as follows: Leu-His (reduction of inflammatory cytokines in microglia) (Ano et al. 2019a); Met-Lys-Pro (suppression of inflammatory cytokines and oxidative stress) (Min et al. 2017); Trp-Tyr and Trp-Met (suppression of microglial inflammation) (Ano et al. 2019b); Gly-Arg (increase of brain-derived neurotrophic factor and the number of neurons) (Katayama et al., 2014); Tyr-Trp, Ile-Tyr, and Ser-Tyr (upregulation of catecholamine metabolism) (Ichinose et al. 2015 \& Ichinose et al., 2020; Moriyasu et al. 2016); Tyr-Leu, Phe-Leu, Trp-Leu (activation of anxiolyticrelated receptors) (Mizushige et al. 2013); and TyrPro (promotion of acetylcholine production) (Tanaka et al. 2020). However, to recognize di/tripeptides as 


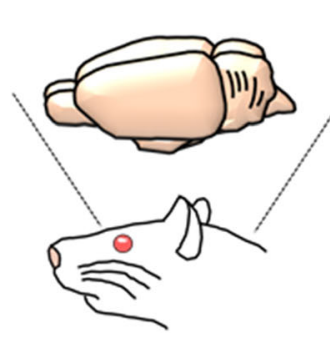

brain sample
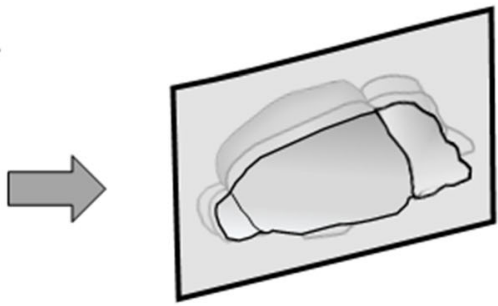

sliced segment

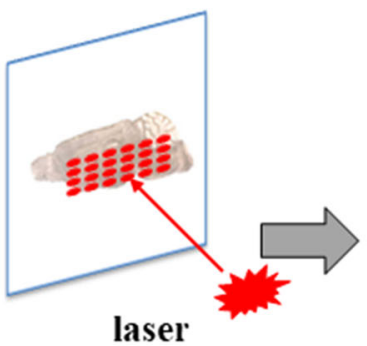

MALDI-MS imaging

ITO-slide
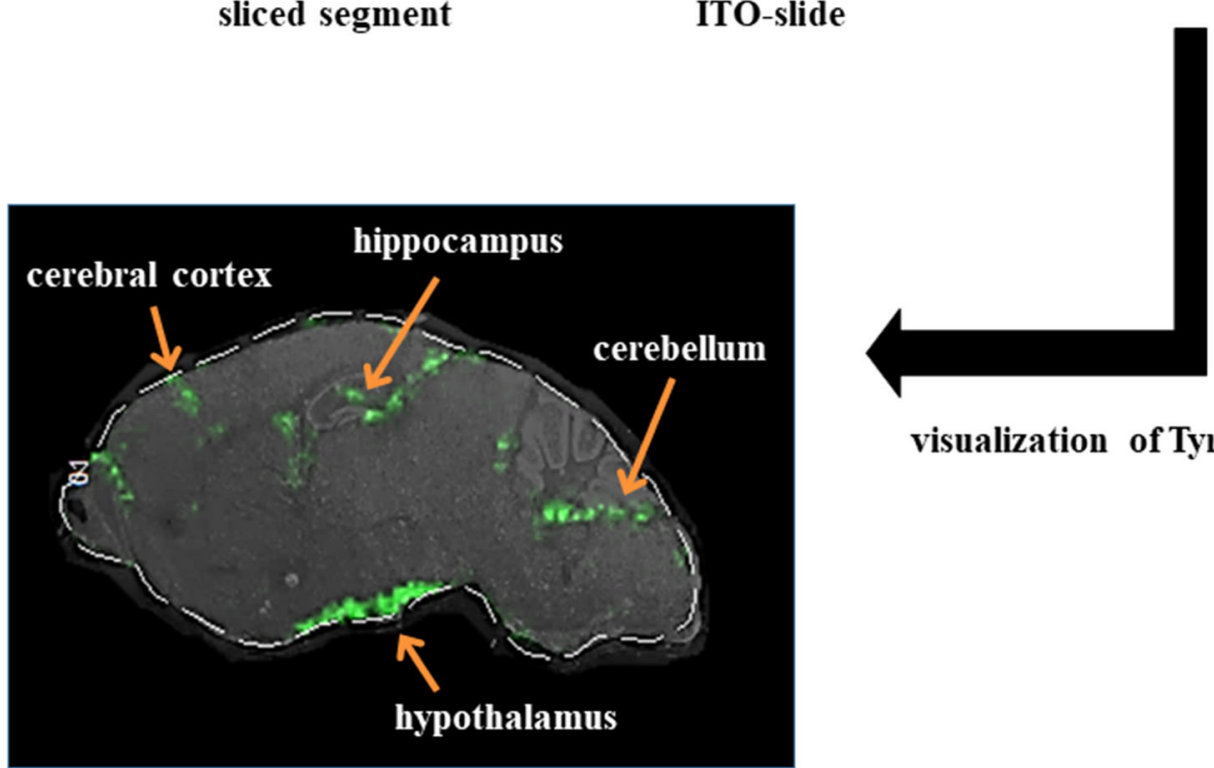

visualization of Tyr-Pro

Fig. 4 Visualized distribution of Tyr-Pro in perfused mouse brain by MALDI-MS imaging. MALDI-MS/MS images of Tyr-Pro ([M + H] $]^{+}, 279.1>116.0$ $\mathrm{m} / \mathrm{z}$ ) display the sagittal tissue and coronal sections of 10-min Tyr-Pro-perfused mouse brain. Scale bar, $2 \mathrm{~mm}$; spatial resolution, $90 \mu \mathrm{m}$

brain-beneficial food compounds, further research is required in the following years to clarify the mechanism(s) of BBB transportation and accumulation in brain parenchyma.

\section{Conclusion}

It seems likely that some dipeptides may cross the severely controlled barrier, $\mathrm{BBB}$, and may accumulate in the brain cerebral parenchyma in intact form. Animal and human studies also provide their brain-health benefit against cognitive decline. However, we still need studies to clarify the underlying mechanism(s) and to see if the benefit carries over to humans.

\section{Abbreviations}

BBB: Blood-brain barrier; RA: Renin-angiotensin; ACE: Angiotensin I-converting enzyme; PepT1: Peptide transporter 1; POT: Proton-coupled oligopeptide transporters; PHT1/2: Peptide-histidine transporters 1/2; TEER: Transendothelial electrical resistance; TJ: Tight-junction; FITC-albumin: Fluorescein isothiocyanate conjugated-albumin; GLUT1: Glucose transporter 1; LAT1: Large neutral amino acid transporter 1; MCT1: Monocarboxylate transporter 1; MALDI-MS: Matrix-assisted laser desorption/ionization mass spectrometry
Acknowledgements

The authors thank Dr. Dohgu S. and Dr. Takata F. for their contributory efforts to brain perfusion study.

Authors' contributions

T. M. designed and conceived the review and all the tables and figures. A. Y. and M.T. contributed to the literature search, the preparation of the tables and figures and the final revision of the manuscript. The authors read and approved the final manuscript.

\section{Funding}

Not applicable.

\section{Availability of data and materials}

The datasets used and/or analyzed during the current study are available from the corresponding author on request.

\section{Competing interests}

The authors declare that they have no competing interests.

Received: 19 August 2020 Accepted: 24 November 2020

Published online: 10 December 2020

\section{References}

Adkison, K. D., \& Shen, D. D. (1996). Uptake of valproic acid into rat brain is mediated by a medium-chain fatty acid transporter. The Journal of Pharmacology and Experimental Therapeutics, 276, 1189-1200.

Alexander, S. P. H., et al. (2015). The concise guide to pharmacology 2015/16: Transporters. British Journal of Pharmacology, 172, 6110-6202. 
Ano, Y., Kita, M., Kitaoka, S., \& Furuyashiki, T. (2019a). Leucine-Histidine dipeptide attenuates microglial activation and emotional disturbances induced by brain inflammation and repeated social defeat stress. Nutrients, 11, 2161.

Ano, Y., Yoshino, Y., Kutsukake, T., Ohyama, R., Fukuda, T., Uchida, K., ... Nakayama, H. (2019b). Tryptophan-related dipeptides in fermented dairy products suppress microglial activation and prevent cognitive decline. Aging, 11, 2949-2967.

Banks, W. A. (2002). Extent and direction of ghrelin transport across the bloodbrain barrier is determined by its unique primary structure. The Journal of Pharmacology and Experimental Therapeutics, 302, 822-827.

Banks, W. A. (2015). Peptides and the blood-brain barrier. Peptides, 72, 16-19.

Banks, W. A., Kastin, A. J., Coy, D. H., \& Angulo, E. (1986). Entry of DSIP peptides into dog CSF: Role of physicochemical and pharmacokinetic parameters. Brain Research Bulletin, 17, 155-158.

Barrera, C. M., Kastin, A. J., \& Banks, W. A. (1987). D-[Ala $\left.{ }^{1}\right]$-peptide T-amide is transported from blood to brain by a saturable system. Brain Research Bulletin, 19, 629-633.

Buckner, R. L. (2013). The cerebellum and cognitive function: 25 years of insight from anatomy and neuroimaging. Neuron, 80, 807-815.

Daniel, H., \& Kottra, G. (2004). The proton oligopeptide cotransporter family SLC15 in physiology and pharmacology. European Journal of Physiology, 447, 610-618.

del Amo, E. M., Urtti, A., \& Yliperttula, M. (2008). Pharmacokinetic role of L-type amino acid transporters LAT1 and LAT2. European Journal of Pharmaceutical Sciences, 35, 161-174

Dias, J., Axelband, F., Lara, L. S., Muzi-Filho, H., \& Vieyra, A. (2017). Is angiotensin(3-4) (Val-Tyr), the shortest angiotensin II-derived peptide, opening new vistas on the renin-angiotensin system? Journal of the Renin-Angiotensin-Aldosterone System, 18, 1-7.

Fei, Y. J., Kanai, Y., Nussberger, S., Ganapathy, V., Leibach, F. H., Romero, M. F., .. Hediger, M. A. (1994). Expression cloning of a mammalian proton-coupled oligopeptide transporter. Nature (London), 368, 563-566.

Guidotti, G., Brambilla, L., \& Rossi, D. (2017). Cell-penetrating peptides: From basic research to clinics. Trends in Pharmacological Sciences, 38, 406-424.

Hata, Y., Yamamoto, M., Ohni, M., Nakajima, K., Nakamura, Y., \& Takano, T. (1996). A placebo-controlled study of the effect of sour milk on blood pressure in hypertensive subjects. American Journal of Clinical Nutrition, 64, 767-771.

Hayes, M., Moen, L. F., Auty, M. A. E., \& Lea, T. E. (2016). Transport of a prolyl endopeptidase inhibitory peptide across the blood-brain barrier demonstrated using the hCMEC/D3 cell line transcytosis assay. Journal of Agricultural and Food Chemistry, 64, 146-150.

Hong, S. M., Tanaka, M., Yoshii, S., Mine, Y., \& Matsui, T. (2013). Enhanced visualization of small peptides absorbed in rat small intestine by phyticacid-aided MALDl-imaging mass spectrometry. Analytical Chemistry, 85, 10033-10039.

Hosoya, K., Ohtsuki, S., \& Terasaki, T. (2002). Recent advances in the brain-to-blood efflux transport across the blood-brain barrier. International Journal of Pharmaceutics, 248, 15-29.

Hu, Y., Xie, Y., Keep, R. F., \& Smith, D. E. (2014). Divergent developmental expression and function of the proton-coupled oligopeptide transporters PepT2 and PhT1 in regional brain slices of mouse and rat. Journal of Neurochemistry, 129, 955-965.

Ichinose, T., Moriyasu, K., Nakahata, A., Tanaka, M., Matsui, T., \& Furuya, S. (2015). Orally administrated dipeptide Ser-Tyr efficiently stimulates noradrenergic turnover in the mouse brain. Bioscience Biotechnology and Biochemistry, 79, 1542-1547

Ichinose, T., Murasawa, H., Ishijima, T., Okada, S., Abe, K., Matsumoto, S., ... Furuya, S. (2020). Tyr-Trp administration facilitates brain norepinephrine metabolism and ameliorates a short-term memory deficit in a mouse model of Alzheimer's disease. PLoS One, 15, e0232233.

Jiang, H., Hu, Y., Keep, R. E., \& Smith, D. E. (2009). Enhanced antinociceptive response to intracerebroventricular kyotorphin in Pept2 null mice. Journal of Neurochemistry, 109, 1536-1543.

Kastin, A. J., \& Akerstrom, V. (1999). Nonsaturable entry of neuropeptide Y into brain. American Journal of Physiology and Metabolism, 276, E479-E482.

Katayama, S., Imai, R., Sugiyama, H., \& Nakamura, S. (2014). Oral administration of soy peptides suppresses cognitive decline by induction of neurotrophic factors in SAMP8 mice. Journal of Agricultural and Food Chemistry, 62, 3563-3569.

Kawasaki, T., Seki, E., Osajima, K., Yoshida, M., Asada, K., Matsui, T., \& Osajima, Y. (2000). Antihypertensive effect of Valyl-tyrosine, a short chain peptide derived from sardine muscle hydrolyzate, on mild hypertensive subjects. Journal of Human Hypertension, 14, 519-523.

Ko, J. H., Lerner, R. P., \& Eidelberg, D. (2015). Effects of levodopa on regional cerebral metabolism and blood flow. Movement Disorders, 30, 54-63.

Liu, K., Ide, J. L., et al. (2013). Molecular imaging of drug transit through the blood-brain barrier with MALDI mass spectrometry imaging. Scientific Reports, 3, 2859.

Maebuchi, M., Kishi, Y., Koikeda, T., \& Furuya, S. (2013). Soy peptide dietary supplementation increases serum dopamine level and improves cognitive dysfunction in subjects with mild cognitive impairment. Japanese Pharmacology \& Therapeitics, 41, 67-74.

Matsui, T., Hayashi, A., Tamaya, K., Matsumoto, K., Kawasaki, T., Murakami, K., \& Kimoto, K. (2003). Depressor effect induced by dipeptide, Val-Tyr, in hypertensive transgenic mice is due, in part, to the suppression of human circulating renin-angiotensin system. Clinical and Experimental Pharmacology and Physiology, 30, 262-265.

Matsui, T., Wang, Z., \& Tanaka, M. (2012). Vascular regulation by small peptides. In G. Brahmachari (Ed.), Bioactive natural products: Opportunities \& challenges in medicinal chemistry, (pp. 201-221). Singapore: World Scientific Publishing.

Min, L. J., Kobayashi, Y., Mogi, M., Tsukuda, K., Yamada, A., Yamauchi, K., .. Horiuchi, M. (2017). Administration of bovine casein-derived peptide prevents cognitive decline in Alzheimer disease model mice. PLoS One, 12, e0171515.

Mine, Y., Li-Chan, E. C. Y., \& Jiang, B. (2010). Bioactive proteins and peptides as functional foods and nutraceuticals. Ames: Wiley-Blackwell.

Mizushige, T., Kanegawa, N., Yamada, A., Ota, A., Kanamoto, R., \& Ohinata, K. (2013). Aromatic amino acid-leucine dipeptides exhibit anxiolytic-like activity in young mice. Neuroscience Letters, 543, 126-129.

Moriyasu, K., Ichinose, T., Nakahata, A., Tanaka, M., Matsui, T., \& Furuya, S. (2016). The dipeptides Ile-Tyr and Ser-Tyr exert distinct effects on catecholamine metabolism in the mouse brainstem. International Journal of Peptides, 2016, 6020786.

Nau, R., Sorgel, F., \& Prange, H. W. (1994). Lipophilicity at pH 7.4 and molecular size govern the entry of the free serum fraction of drugs into the cerebrospinal fluid in humans with uninflamed meninges. Journal of the Neurological Sciences, 122, 61-65.

Nguyen, H. N., Ham, T. H., Matsui, T., \& Tanaka, M. (2019). Detection and visualization of food-derived polyphenols by matrix-assisted laser desorption/ ionization mass spectrometry imaging. Sensors and Materials, 31, 2333-2346.

Ogawa, K., Kato, N., \& Kawakami, S. (2020). Recent strategies for targeted brain drug delivery. Chemical and Pharmaceutical Bulletin, 68, 567-582.

Pan, W., et al. (2005). Permeation of growth hormone across the blood-brain barrier. Endocrinology, 146, 4898-4904.

Rhee, M., \& Davis, P. (2006). Mechanism of uptake of C105Y, a novel cellpenetrating peptide. Journal of Biological Chemistry, 281, 1233-1240.

Shariatgorji, M., Nilsson, A., Goodwin, R. J. A., Kallback, P., Schintu, N., Zhang, X., ... Anderen, P. E. (2014). Direct targeted quantitative molecular imaging of neurotransmitters in brain tissue sections. Neuron, 84, 697-707.

Squire, L. R., Genzel, L., Wixted, J. T., \& Morris, R. G. (2015). Memory consolidation. Cold Spring Harbor Perspectives in Biology, 7, a021766.

Tanaka, M., Dohgu, S., Komabayashi, G., Kiyohara, H., Takata, F., Kataoka, Y., ... Matsui, T. (2019). Brain-transportable dipeptides across the blood-brain barrier in mice. Scientific Reports, 9, 5769.

Tanaka, M., Kiyohara, H., Yoshino, A., Nakano, A., Takata, F., Dohgu, S., ... Matsui, T. (2020). Brain-transportable soy dipeptide, Tyr-pro, attenuates amyloid $\beta$ peptide $25-35$-induced memory impairment in mice. npj Science of Food, 4, 7-10.

Tsuruoka, N., Beppu, Y., Koda, H., Doe, N., Watanabe, H., \& Abe, K. (2012). A DKP cyclo(L-Phe-L-Phe) found in chicken essence is a dual inhibitor of the serotonin transporter and acetylcholinesterase. PLOS One, 7, e50824.

Xiang, J., Hu, Y., Smith, D. E., \& Keep, R. F. (2006). Pept2-mediated transport of 5aminolevulinic acid and carnosine in astrocytes. Brain Research, 1122, 18-23.

Yamashita, T., Shimada, S., Guo, W., Sato, K., Kohmura, E., Hayakawa, T., ... Tohyama, M. (1997). Cloning and functional expression of a brain peptide/ histidine transporter. Journal of Biological Chemistry, 272, 10205-10211.

Yoshimura, Y., \& Zaima, N. (2020). Application of mass spectroscopy imaging for visualizing food components. Foods, 9, 575.

\section{Publisher's Note}

Springer Nature remains neutral with regard to jurisdictional claims in published maps and institutional affiliations. 